\title{
Internships for Credit: Linking Work Experience to Political Science Learning Objectives
}

\author{
Kevin Edward Lucas, Capital University \\ klucas2@capital.edu
}

Paper prepared for the $16^{\text {th }}$ American Political Science Association Teaching \& Learning Conference, Albuquerque, February 7-9, 2020

Preliminary Draft 


\begin{abstract}
:
The ever-rising costs of higher education in the United States have combined with a job market in which starting salaries have remained stagnant in many fields to create a situation in which many undergraduate students adopt a relatively narrow cost-benefit analysis when choosing their majors and minors, when choosing the specific courses they take, and when choosing the extra-curricular activities in which they will participate. For students studying Political Science at the undergraduate level who are increasingly concerned about their marketability, the possibility of receiving academic credit while completing an internship is often an appealing option. However, for faculty members who have been given the responsibility of supervising these experiences, it can be difficult to establish clear guidelines regarding what a student must do - in terms of the type of organization where the student does his/her internship, the type of on-the-job tasks that the student performs while completing the internship, and the type of complementary academic assignments that the student is asked to submit to the faculty advisor - in order to receive academic credit that can be applied towards completion of the Political Science major. In this paper, I examine the syllabi that a number of US colleges and universities use for credit-bearing Political Science Internship courses, and I also reflect on my own experience of supervising the academic component of such courses, in order to generate a list of suggested "best practices" designed to ensure that students deserve the academic credits they receive and to ensure that their internship experiences do indeed enhance their marketability.
\end{abstract}


Responding to research (cite literature on the demand for, and benefits of, internships)

that demonstrates the positive impact that internships can have on student success, most colleges and universities encourage their students to pursue and take advantage of opportunities to complete internships related to their future career goals while they pursue their undergraduate degree. The form that this encouragement takes, however, varies greatly. At some colleges and universities, this encouragement may indeed be just that - encouragement, generally in the form of informal advice that instructors and professional staff give to their students during advising meetings, in the classroom, and/or during first-year orientation sessions. Many institutions go beyond this and provide dedicated professional staff - often in an Office of Career Services or some similarly-named, centralized, on-campus support office - who work with students to help them find and apply for job and internship opportunities. Some institutions, particularly those with larger enrollments, may supplement the work done by centralized career services offices by providing a specific faculty or staff member who works solely with students who are majoring in one of a set of related disciplines (e.g., the social sciences), or even with students from a single academic department (e.g. Political Science).

Beyond providing encouragement and making career planning services available to students, some institutions go a step further by allowing students to receive academic credit for completing internships. One rationale for permitting students to earn credit towards the completion of their degree by completing a relevant internship is to make it easier for students to juggle the scheduling demands associated with taking a full load of courses while simultaneously working as an intern. Particularly for students who work during the academic year and for those who have other extracurricular commitments (e.g., intercollegiate athletics, leadership positions in student organizations) that place significant demands on their time, the ability to earn 
academic credit while completing an internship may help make it possible for these students to fit a meaningful internship experience into their busy and often relatively inflexible schedules. Additionally, the ability to earn academic credit for completing an internship provides all students with an additional incentive to do so.

In terms of how these programs are organized and how the credits earned by completing an internship are counted towards fulfillment of a student's graduation requirements, for-credit internships come in a variety of shapes and sizes. At many institutions, the academic credits that students earn while completing their internships are counted as general electives (oftentimes on a pass/fail basis); the credits count towards the minimum number of credits that a student must complete in order to graduate, but they do not fulfill any specific general education requirement nor are they counted towards the completion of a student's major. However, some colleges and universities - or, in some cases, specific academic departments within these institutions - allow credits earned while completing an internship to be applied towards the student's major requirements.

This arrangement itself can also take a number of different forms. At some institutions, only specific internship programs that are either sponsored or explicitly approved by the university and/or academic department are accepted as partial fulfillment of the student's major requirements. In Political Science, these programs often take the form of long-established "summer in Washington" or "semester in Washington" programs that allow students the opportunity to reside and work in the nation's capital, essentially taking a temporary leave of absence from their home institution. Other colleges and universities that allow students to earn credit towards the completion of the Political Science major by completing a relevant internship accept a broader range of internship experiences. 
Generally speaking, institutions that allow students to apply the academic credits they earn while completing an internship towards fulfilling the requirements for their major accept these credits as elective credits, but this certainly is not the only possible arrangement. At some institutions, the completion of a relevant internship is one of the core requirements that all students must fulfill in order to graduate with a degree in Political Science. The institution where I teach, and where I serve as the de facto coordinator of the Political Science internship program - Capital University in Columbus, Ohio - has adopted a middle position; students must either complete an internship or write a senior thesis in order to fulfill the capstone experience requirement for the Political Science major.

Regardless of whether internship credits are applied as elective credits or used to fulfill a core requirement for the major, granting Political Science credit for the completion of an internship raises a number of interesting and important questions. What sort of internship experience qualifies as a "Political Science internship?" How can internship courses be designed so that they help students achieve some of the learning objectives that Political Science departments typically set forth for their students? Towards that end, what sort of academic assignments should students be required to complete in conjunction with their internship experience? How should student grades be determined? After a brief description of my own experience, the rest of this essay will consist of an examination of these issues that will culminate with the presentation of a set of suggested "best practices" that might be followed to ensure that students who receive Political Science credits for completing an internship truly deserve those credits and to ensure that the internship experience itself contributes towards the students' achievement of the learning objectives that Political Science departments set for their students. 


\section{$\underline{\text { Political Science Internships at Capital University }}$}

I inherited the stewardship of Capital University's Political Science internship program in April 2018, when the professor who had previously filled that position abruptly left the university to pursue other opportunities. As soon as word of my former colleague's pending departure reached the student body, I was approached by one particularly anxious student who had already made arrangements to do a for-credit internship during the upcoming summer; would I be willing to replace my soon-to-be ex-colleague as the instructor of POLS 495 (our designation for the Political Science Internship course)? After determining what that would entail from an administrative standpoint and familiarizing myself with the university's and the department's requirements for the course, I set out to make POLS 495 mine by revamping the syllabus that my predecessor had used, a syllabus that included a single assignment; students were required to select one from a list of fourteen political theory/philosophy texts and write a "manual of advice for those in power" (inspired by Machiavelli's The Prince) based on the chosen text and on the student's internship experiences.

The syllabus I use now, which is still a work in progress, was inspired by my examination of syllabi used at more than a dozen colleges and universities, the academic coursework I completed as a participant in a year-long work/study program in Ecuador organized by the University of Minnesota's Minnesota Studies in International Development program, the quarterly reports I was required to compile as a Peace Corps Municipal Development Volunteer in El Salvador, conversations with faculty colleagues from a variety of academic disciplines who participate in Capital University's Internship Community of Practice, and feedback from the seven students who took POLS 495 with me in the Summer and Fall of 2018. This syllabus includes a range of assignments designed to encourage students to document and reflect upon 
their internship experience and to conduct research on a specific issue related to political science, public policy, public administration, or the law that intersects with the work they performed while completing their internship.

To date (not including the current semester), I have supervised eleven students who have successfully completed POLS 495 and a twelfth student who used the same syllabus and set of assignments while completing an internship as her capstone experience for the International Studies major. Those twelve students have completed their internships with a wide range of organizations, including government agencies, political campaigns, law firms, non-governmental organizations, and even a rendering plant. I provide more detail about their experiences, and about the way I used academic assignments to help my students connect their internship experiences to the achievement of Political Science-specific learning objectives, later in this essay.

What is a Political Science Internship?

Presumably, if a student is going to receive Political Science credit (rather than simply general education credit) for having completed an internship, that internship should have some connection to the world of politics. The question is, what sort of internship experiences should and should not qualify as political science internships? In this regard, we face an interesting obstacle that colleagues in many other disciplines do not face. At my own institution, many of the other disciplines that offer/require for-credit internships or internship-like experiences are preparing students for a relatively narrow set of career paths, so the task of determining whether an internship is relevant or not is usually a simple one. So, nursing majors complete nursing clinicals, accounting majors intern with accounting firms, education majors perform student 
teaching, exercise science majors gain experience as personal trainers through an on-campus program open to faculty and staff, and music technology majors complete internships at recording studios, radio stations, performance venues, or other similar environments. Where do students turn to complete an internship in political science?

The official catalog description for the Political Science Internship course that I teach reads:

"Practicum through placement in state, local or federal government agency, expressly political organization, or political campaign. Academic coursework will be supervised by a member of the faculty."

Thanks in part to the fact that my institution is located in (and, indeed, named for) the state capital, some of the students who I have supervised have found internships that clearly meet this requirement. Since I took over the stewardship of Capital University's Political Science Internship program, three students have interned with state or local government agencies while two others have completed internships with political campaigns. For those five students, it was quite clear that their internships met our stated requirements.

Of course, students who major in Political Science do not all pursue careers in public service, party politics, or with an "expressly political organization." Many students who pursue an undergraduate degree in Political Science do so because they see the degree as a springboard to law school and eventual employment as an attorney. Others use the research, analytical, and communication skills that they hone while completing their Political Science degree to pursue careers in education, public relations, marketing, journalism, or the business world. Recognizing that an undergraduate degree in Political Science does not prepare students only to work in politics, I believe that it is appropriate to adopt a fairly lenient approach, one that reflects the breadth of paths that our students embark upon after graduation, when determining what sort of 
internship experience should be accepted for Political Science credit. For example, although most law firms are not "expressly political organizations," it would be counter-productive to discourage a student - particularly a student who intends to enroll in law school following completion of his/her undergraduate degree - from interning at a law firm. Generally speaking, it is difficult to find a rationale for discouraging a student from completing any internship that would likely provide him/her with opportunities to achieve one or more of the learning objectives that Political Science departments hope their students will attain.

A trickier issue arises when we change our focus from where a student interns to what tasks and responsibilities he/she will be given while performing his/her internship. Ultimately, neither the student nor the faculty member who supervises the academic portion of a for-credit internship experience has much leverage over the student's on-the-job supervisor. Memoranda of understanding signed by the student, the faculty supervisor, and the person who will supervise the student while he/she completes his/her internship that state each party's expectations regarding the student's internship experience, as well as site visits conducted by the faculty supervisor (when feasible), may increase the likelihood that the student will be given appropriate tasks and responsibilities, but they cannot guarantee that the student will not spend the vast majority of his/her time completing menial tasks that are unlikely to contribute much to the student's academic or professional development (as happened with one of my students who interned with a law firm and who spent nearly all of his time digitizing and filing documents). This worst-case scenario highlights the importance of designing academic assignments that will allow the student to benefit from the internship experience - and to make progress towards achieving learning objectives typically associated with a degree in Political Science - even if the internship itself is ultimately unfulfilling. 


\section{Internships and Political Science Learning Objectives}

There may be as many different sets of learning objectives for Political Science majors as there are colleges and universities that offer a Political Science major. For this discussion, I will employ the list of "departmental learning outcomes" developed by the Department of Political Science at the University of Oregon. This list of nine learning objectives is reproduced in its entirety in the appendix; an abbreviated version appears here:

1) Recognize and describe major variations in political institutions and policy processes.

2) Recognize the roles played by various actors, groups, and movements in political and cultural processes.

3) Identify the defining principles of major political ideologies and apply their perspectives to political issues.

4) Describe how power, agency, and authority are constituted, disseminated, and exercised.

5) Analyze, interpret, and explain why and how political processes or policy outcomes vary.

6) Construct a sustained argument evaluating a theoretical claim against alternative theoretical traditions or perspectives and appropriate evidence.

7) Identify and describe several analytical methods that political scientists use to study political phenomena.

8) Demonstrate engagement with social and political issues.

9) Produce clear and professional verbal and written communication.

I choose to employ this list of learning outcomes for three main reasons. First, because it incorporates both institutional and behavioral approaches to the study of political outcomes.

Second, because it emphasizes the research, analytical, and communication skills that help Political Science graduates succeed in a variety of fields. Third, because it also includes social and political engagement as an objective.

How might the tasks that students complete while interning help them achieve these objectives? The answer to that question is contingent upon each student's internship experience. Students who intern with a political campaign may witness the roles played by various actors, groups, and movements in political and cultural processes (objective \#2), they may see the 
exercise of power and authority (objective \#4), they almost certainly will engage with social and political issues (objective \#8), and they may be asked to produce clear and professional verbal and written communication (objective \#9). Students who intern with a government agency may improve their ability to recognize and describe variations in political institutions and policy processes (objective \#1), to describe how power, agency, and authority are constituted, disseminated, and exercised (objective \#4), to analyze, interpret, and explain political processes or policy outcomes (objective \#5), and to produce clear and professional verbal and written communication (objective \#9). Students who complete their internship with some sort of expressly political non-governmental organization are also likely to make progress towards achieving a number of these learning objectives; depending on the organization and the role that the intern is expected to play, the student may gain a better understanding of variations in political institutions and policy processes (objective \#1), of the roles played by various actors, groups, and movements in political and cultural processes (objective \#2), and of the ways that power, agency, and authority are constituted, disseminated, and exercised (objective \#4); he/she will certainly engage with social and political issues (objective \#8), and he/she may be called on to analyze, interpret, and explain political processes or policy outcomes (objective \#5) and to produce clear and professional verbal and written communication (objective \#9).

While students who intern with a law firm, or who find an internship in the business world, might not have opportunities to achieve as many of these learning objectives as students who complete an internship that is more political in nature, these types of internships often provide students with valuable opportunities to utilize and refine their research, analytical, and communication skills. Also, it is important to remember that there is no guarantee that an internship with a government agency, or a political campaign, or a non-governmental 
organization involved in politics and/or policy will necessarily provide the student with all - or even any - of the opportunities described in the previous paragraph. Which is better, in terms of making progress towards achieving learning objectives associated with the completion of a degree in Political Science, (1) an internship with a political campaign in which the student's sole task is to lick stamps and affix them to campaign mailing or (2) an internship with the office staff of a rendering plant that gives the student the opportunity to participate in meetings with

officials from the U.S Department of Agriculture, the Occupational Safety and Health Administration (OSHA), and a variety of state and local governmental agencies? Again, I conclude this section with the suggestion that variety in the extent to which student interns will be given opportunities to achieve specific learning objectives demonstrates the importance of designing academic assignments that will complement the internship experience in a way that helps justify awarding the student with Political Science credit for completing an internship. It is to that topic that I now turn.

\section{Political Science Internships: The Academic Side}

In the current iteration of my POLS 495 syllabus, I require students to complete six written assignments and to give one oral presentation. Early in the semester, students must complete an Internship Learning Objectives form in which they detail the professional, academic, and personal goals they hope to achieve while completing their internship. Three Progress Reports give students the opportunity to document and describe the work they have completed and the skills they have learned while performing their internship and to reflect upon the extent to which the internship experience has lived up to their initial expectations. These four assignments are all designed to highlight the generalized professional and personal 
development aspects of the internship experience; none are explicitly geared towards any learning objectives that might be considered unique to the Political Science major.

The two main written assignments, each due at the end of the semester, are the Final Report and Portfolio and the Internship Reflection Paper. The Final Report and Portfolio consists of four distinct components: (1) a 2-3 page report that requires students to reflect upon the knowledge and skills they learned while completing their internship and relate them to both the study of Political Science and their career goals, (2) a 2-3 page evaluation of the student's supervisor(s) and the organization where he/she completed his/her internship that forces the student to analyze the political and social roles that the organization plays and to evaluate its effectiveness, (3) a resume, and (4) a portfolio including documents and/or artifacts that the student created while performing his/her internship. While components \#3 and \#4 are, like the Internship Learning Objectives form and the Progress Reports, primarily designed to accentuate the very general goals associated with any sort of internship experience, components \#1 and especially $\# 2$ are more closely aligned with Political Science-specific learning objectives.

The actual "report" part of this Final Report and Portfolio, by explicitly requiring students to identify relationships between knowledge and skills they have learned on the job and those they have learned in the classroom, may (depending on the nature of the internship experience) contribute to students' ability to recognize and describe major variations in political institutions and policy processes (objective \#1), to recognize the roles played by various actors, groups, and movements in political and cultural processes (objective \#2), and to describe how power, agency, and authority are constituted, disseminated, and exercised (objective \#4). Evaluating the agency where the student completed his/her internship may contribute to helping the student achieve those same learning objectives, and it may also provide the student with an 
opportunity to demonstrate his/her ability to analyze, interpret, and explain why and how political processes or policy outcomes vary (objective \#5).

The Internship Reflection Paper, which is the single-most important assignment in terms of its contribution to the student's final grade, requires the student to "write an essay that explores the linkages between his/her internship experience and relevant ongoing research/debates in the fields of Political Science, Law, and/or Public Administration.” By design, I do not include any lengthy description of the expectations for this assignment on the syllabus. Rather, I explain to the students that this assignment is meant to bridge the gap between a research paper and an opinion piece. Students are expected to conduct a survey of research on a specific topic that is in some way related either to the work that the student performed while completing his/her internship or to work that the internship agency performs, but they are also instructed to interject their own voice into the debate. To date, I have been consistently impressed by student performance on this assignment. These reflection papers (which are listed in Table 1) have both demonstrated and contributed to the development of students' abilities to recognize and describe major variations in political institutions and policy processes (objective \#1), to recognize the roles played by various actors, groups, and movements in political and cultural processes (objective \#2), to identify the defining principles of major political ideologies and apply their perspectives to political issues (objective \#3), to describe how power, agency, and authority are constituted, disseminated, and exercised (objective \#4), to analyze, interpret, and explain why and how political processes or policy outcomes vary (objective \#5), and to construct a sustained argument evaluating a theoretical claim against alternative theoretical traditions or perspectives and appropriate evidence (objective \#6). A few examples warrant further examination. 


\section{Table 1 - Internships and Reflection Paper Topics}

\section{Type of Internship}

Government Agency (City Prosecutors' Office)

Government Agency (State Department

of Transportation)

Government Agency (County Juvenile Court)

Campaign Internship (Congressional

Campaign)

Campaign Internship (State Party

Office)

Legal Internship (Law Firm

Specializing in Elder Law)

Legal Internship (Law Firm

Specializing in Contract Law)

Legal Internship (Immigration

Attorney)

Non-Governmental Organization

(Political Lobbying Group)

Non-Governmental Organization (FaithBased Educational Organization)

Business Internship (Rendering Plant)

\section{Reflection Paper}

Vehicular Homicide, Aggravated Vehicular Homicide, and

Vehicular Manslaughter

Notes on the Ohio Department of Transportation and Exploration of Topics Relating to the Limitations of Present American Transportation

Juvenile Detention Alternatives Initiative

The Effectiveness of Canvassing

Importance of Correctly Interpreting Polls

Elder Abuse

Contracts and the Field of Sports Law

Immigration Policy After 9/11 Attacks and the Trump

Presidency

Young Americans for Liberty and Incarceration Nation

The Benefits of Afterschool Programs

Animal Rights and the Rendering Industry

The aforementioned "particularly anxious student" who is at least partly responsible for launching me onto the path that resulted in me becoming the de facto coordinator of Capital University’s Political Science internship program completed her internship with the City Prosecutors' Office in Athens, Ohio. As part of her internship experience, she assisted the Prosecutors' Office as it prepared for the trial of a defendant who had struck and killed a man who was riding his bicycle on the shoulder of a rural highway. Using her knowledge of the specifics of that case, research she conducted on the Ohio state laws pertaining to vehicular manslaughter and vehicular homicide, and the examination of a number of relevant court cases, this student wrote an impressive exploration of arguments for and against the criminalization of vehicular accidents that result in the death of one or more individuals. Another student who 
completed an internship with the Juvenile and Probate Court in Fairfield County, Ohio, drew upon his involvement with the Court's efforts to become certified by the Anne E. Casey Foundation's Juvenile Detention Alternatives Initiative and his examination of research on the effectiveness of various alternatives to juvenile detention to write an essay focused on the need for juvenile justice reform as it pertains to the disproportionate number of African-American and Hispanic youths who are sent to juvenile detention centers. A third student, who completed an internship with a law firm that specializes in elder law, was inspired by the stories she heard from clients and from the legal professionals she worked with to write an essay on elder abuse that examined parallels between the physical forms of abuse that elders all too frequently suffer at nursing homes and other assisted living facilities and the various forms of financial abuse that also victimize many senior citizens. All of these papers demonstrated the research, analytical, and communication skills that we hope our students will acquire while completing their Political Science degree.

\section{Evaluating the Internship Experience}

When it comes to for-credit internships that fulfill requirements for the Political Science major, some decision must be made about how students' grades will be determined. One approach would be to grade internship courses on a pass/fail basis. Taking into consideration the fact that most relevant internship experiences will take place off campus and away from the gaze of any faculty supervisor, this option carries with it a certain undeniable appeal. However, if the internship course can be taken in place of a senior thesis (as is the case at the institution where I work), this approach may be difficult to justify; why should students who choose the thesis option need to be concerned about a letter grade if students who instead opt to complete an 
internship only need to pass their senior capstone experience? The need to assign a letter grade to the student's internship experience provides yet another rationale for requiring students to complete a range of written assignments designed to complement the learning that takes place at the internship site.

\section{$\underline{\text { Conclusions }}$}

With students adopting a relatively narrow cost-benefit analysis when choosing what school they will attend, what major they will choose, and what courses they will take, Political Science departments would do well to think about ways they can enhance the marketability of their graduates. Encouraging students to perform relevant internships by offering them the opportunity to receive academic credit for their internship experiences is one important way that Political Science departments can contribute to students' professional development. However, once we enter the realm of allowing students to use credits earned while completing an internship to fulfill major requirements, it is important that these internship experiences contribute to students' achievement of discipline-specific learning objectives. By creating academic assignments that complement the internship experience and that require students to utilize the research, analytical, and communication skills that bolster the general marketability of students who graduate with an undergraduate degree in Political Science, we can ensure that students who receive Political Science credits from an internship course deserve those credits. 


\section{Works Consulted}

Hummer, Hill Abraham. 2012. "The Content of Capstone Experiences: Determining Best Practices in Assessing the Culmination of Student Learning." Paper presented at the American Political Science Association Teaching and Learning Conference, Washington D.C., February 17-19.

McClellan, E. Fletcher. 2015. "Best practices in the American undergraduate political science curriculum.” In John Ishiyama, William J. Miller, and Eszter Simon, eds. Handbook on Teaching and Learning in Political Science and International Relations. Northampton, MA: Edward Elgar Publishing: 3-15.

University of Oregon, Department of Political Science. n.d. "Grade Meanings and Learning Outcomes." polisci.uoregon.edu/grade-meanings-and-learning-outcomes/.

Wahlke, John C. 1991. "Liberal Learning and the Political Science Major: A Report to the Profession." PS: Political Science \& Politics, 24(1): 48.

\section{$\underline{\text { Syllabi Consulted }}$}

- Calvin University. POLS 380: Internship in Politics and Government.

- College of Wooster. Experiential Learning at The College of Wooster: Guide to CreditBearing Internships.

- Eastern Michigan University. Political Science Internship Seminar.

- Grand Valley State University. Internship Program in Political Science or International Relations.

○ Northern Illinois University. POLS 490 - Political Science Internship.

- Oakland University. PA 6950 Public Administration Internship Capstone Course.

- Ohio State University. Political Science 4191 Student Internship in American Politics.

- Radford University. Department of Political Science Internships Manual.

- Rutgers University. Internship in Political Science.

- Southern Maine Community College. Political Science Internship Course Syllabus.

- Tennessee State University. COMM 3950, Internship.

- University of California, Los Angeles. Political Science 195CE Civic Engagement Internship.

- University of Minnesota. POL 3080 Internship in Politics or Government.

- University of Nevada, Reno. Internship Syllabus.

- University of Wisconsin, Milwaukee. Internship Contract, Political Science 489: Internship in Political Science.

○ Washington State University. Political Science 498 Public Policy Internship. 


\section{Appendix: Excerpts from POLS 495 Syllabus, Capital University, Spring 2020}

\section{Course Description}

Practicum through placement in state, local, or federal government agency, expressly political organization, or political campaign. Academic coursework will be supervised by a member of the faculty. No more than six hours can be taken in total. 3-6 Credit Hours.

Work Hours and Academic Credit: Students are eligible to receive 1 hour of academic credit for every 45 hours of work completed during the internship, up to a maximum of 6 credit hours.

\section{Course Goals \& Intended Learning Outcomes}

There are two primary aims of the Political Science internship program. The first is for students to observe the world of practical politics and meet the practitioners in relevant fields. The second is to bring the academic content students have studied in the classroom into conversation with those practices. In a crude sense, the internships present students with the opportunity to experience some aspect from the wide set of occupations pertaining to the world of politics. In that regard, they are an opportunity to meet people working, in some way, in the field.

Concurrently, the internship provides students with another environment to do what they should have been doing throughout the collegiate experience: drawing connections between the lessons of the classroom and the practices of everyday life. Supervision of the internship will proceed accordingly.

Intended Learning Outcomes:

- Demonstrate leadership skills and professional behaviors through curricular and cocurricular activities in the respective discipline (i.e., political science, international studies, public administration, and economics and political science).

- Reason logically about and critically evaluate issues in the respective discipline.

\section{Evaluation}

Grades will be calculated as follows:

\section{Grade Calculation:}

Internship Learning Objectives Form $\quad 10 \%$

Progress Reports (3) $\quad 15 \%$

Reading List $\quad 5 \%$

Final Report and Portfolio $\quad 15 \%$

Internship Reflection Paper $\quad 35 \%$

Performance Evaluation $\quad 10 \%$

Oral Presentation $\quad 10 \%$ 


\section{Assignments}

Internship Learning Objectives Form: Each student must complete and submit a summary of his/her learning objectives, using the "Learning Objectives Form" that will be emailed to all students. The completed form should be 2-4 pages in length (single-spaced). This assignment is due (via email) at 2:00pm on Friday, January 24.

Progress Reports: Students will submit three Progress Reports, using the "Progress Report Forms" that will be emailed to all students before they begin their internships. These Progress Reports are due, via email, at 2:00pm on the following dates: January 29, February 21, and March 20.

Performance Evaluation: Students will provide the faculty member with contact information for their internship supervisor(s). The faculty member will solicit an evaluation on student performance from the supervisor in early March. Although evaluations must come directly from the supervisor(s), it is the student's responsibility to ensure that responses are received by Tuesday, April 14.

Final Report and Portfolio: Each student must complete and submit a final report and portfolio that includes the following four components:

1) A report that summarizes the internship experience, focusing on the degree to which the student successfully fulfilled his/her professional, civic, academic, and personal learning objectives.

- For this section of the assignment, you should do more than just cut and paste from your Progress Reports; I will have read them, and will not need to read them again. Instead, you should focus on the big picture. What did you learn, and what skills did you develop while completing your internship? How did the knowledge you gained during your internship experience either complement or contradict the lessons you have learned taking Political Science courses? How might the knowledge you have gained and the skills that you have learned help you in future courses and, more importantly, once you leave Capital University and enter the real world? This section of the assignment should be 2-3 pages in length.

2) An evaluation of the student's supervisor(s) and his/her counterpart agency that addresses each of the following questions: (1) Did the organization provide the intern with suitable tasks/projects and provide him/her with appropriate support and supervision? (2) How well - from the intern's point of view - does the organization serve the public by fulfilling its political/social/administrative role(s)? (3) How could the organization's effectiveness be improved? (4) Would you recommend your internship to future Capital students?

- Address all four questions, but focus most of your attention on questions \#2 and \#3. This part of the assignment should also be $\mathbf{2 - 3}$ pages in length. 
3) A resume that includes the student's professional objective(s), educational experience, work experience (including the internship experience), and other relevant experience.

- Limit your resume to a single page, and tailor it to whatever you think your immediate postCapital future holds - in other words, if you will be continuing on to law school or to graduate school after you finish your BA, write a resume with that in mind; if you will be entering the job market, write a resume that is geared towards that goal. I do not have any specific requirements about formatting - just make it look professional.

4) If appropriate, a portfolio that includes sample documents/artifacts that the student created while completing the tasks that he/she was assigned. For example, if the student was responsible for creating any reports or documents for use by the counterpart agency, the portfolio should include copies of some of those reports/documents.

- Regarding the portfolio, more is better. Think of this as the "show and tell" portion of the assignment. Images, documents you created, documents you worked with ... anything that provides some visual documentation of the tasks you completed while interning would be a welcome addition to your portfolio.

- You only need to include the portfolio with the final draft of your report. Also, you do not need to digitize items such as photographs, brochures, etc. It is sufficient to simply provide me with physical copies of such materials.

Students must email the instructor the first draft of their report and portfolio by $\mathbf{2 : 0 0 p m}$ on Monday, March 30. The final draft must be uploaded to iLearn by 2:00pm on Tuesday, April 14, and a hard copy must be brought to my office by 4:00pm that same day.

Internship Reflection Paper: Using appropriate academic texts (see the section on "Required Readings" for details about the selection of appropriate texts) as a foundation, each student will write an essay that explores the linkages between his/her internship experience and relevant ongoing research/debates in the fields of Political Science, Law, and/or Public Administration.

The minimum length of this essay will correspond to the number of credit hours to be awarded; essays must be at least 1,000 words per credit hour in length. So, for a student who takes POLS 495 for 3 credit hours, the Internship Reflection Paper would have to be at least 3,000 words in length.

The first draft must be emailed to the instructor by 2:00pm on Monday, March 30. Students must bring two hard copies of the first draft of their paper to our class meeting on Friday, April 3. The first draft must be at least $80 \%$ of the required length of the final draft.

The final draft must be uploaded to iLearn by 2:00pm on Tuesday, April 14, and a hard copy must be brought to my office by $4: 00 \mathrm{pm}$ that same day.

Oral Presentation: On Friday, April 17, each student will give a 12-15 minute presentation that provides a summary of the materials included in the Final Report and Portfolio and in the Internship Reflection Paper. 


\section{Required Readings}

Students are responsible for identifying (and, of course, reading) a set of no fewer than eight readings that present/discuss ongoing debates in the fields of Political Science, Law, and/or Public Administration that are directly relevant to the nature of and/or work done by the counterpart agency. For instance, a student who completes his/her internship working on a political campaign might choose a set of readings that focus on campaign strategies, or on campaign finance, or on partisanship, etc. Similarly, a student who completes his/her internship working in a local prosecutor's office might choose a set of reading that focus on mandatory sentencing guidelines, or on prosecutorial discretion, or on racial/ethnic/socioeconomic disparities in the severity of charges that are brought forth for similar crimes, etc. At least five of the eight selected readings must be from academic sources - peer reviewed articles, books published by university presses (or other scholarly presses), or law review articles. If the student has any questions about whether a reading qualifies as an academic source, he/she should consult with the instructor.

Students must email their reading list to the instructor no later than 2:00pm on Friday, February 14.

\section{Course Calendar}

Friday, January 10

Friday, January 24

Wednesday, January 29

Friday, January 31

Friday, February 14

Friday, February 21

Friday, March 6

Friday, March 20

Monday, March 30

Friday, April 3

Tuesday, April 14

Friday, April 17
Class Meeting \#1 - Welcome to POLS 495

Internship Learning Objectives Form due (by 2pm)

Progress Report \#1 due (by 2pm)

Class Meeting \#2

Reading List due (by 2pm)

Progress Report \#2 due (by 2pm)

Class Meeting \#3

Progress Report \#3 due (by 2pm)

Final Report and Portfolio - first draft due (by 2pm) Internship Reflection Paper - first draft due (by 2pm)

Class Meeting \#4 - Peer Review Session

Final Report and Portfolio - final draft due Internship Reflection Paper - final draft due Performance Evaluation due

Class Meeting \#5 - Student Presentations 


\section{Internship Learning Objectives $\quad<$ Name $>><$ Date $>>$}

Complete this form and send it via email to Dr. Lucas (klucas2@capital.edu) by the due date listed on the syllabus.

\section{Professional Objectives}

How do you expect this internship will help you pursue your career goals?

$<<$ answer $>>$

\section{Civic Objectives}

What political knowledge and/or civic skills (e.g., public speaking, writing, financial literacy, cultural competency, leadership, teamwork, etc.) do you hope to obtain while completing this internship?

$<<$ answer $>>$

\section{Academic Objectives}

How do you expect to apply what you have learned as a student of political science and/or international studies while completing your internship?

$<<$ answer $>>$

Do you expect your internship to confirm or disconfirm what you have learned as a student of political science and/or international studies? Why?

$<<$ answer $>>$

\section{Personal Objectives}

How do you expect the internship will contribute to your growth as an individual, as a citizen, and as a political actor?

$<<$ answer $>>$ 


\section{Internship Progress Report \#1 $\quad<$ Name $>><$ Date $>>$}

Complete this form and send it via email to Dr. Lucas (klucas2@,capital.edu) by the due date listed on the syllabus.

\section{Internship Information:}

What is the name of the organization where you are interning?

$<<$ answer $>>$

How did you receive this internship?

$<<$ answer $>>$

Do you have a specific title at your internship? If so, what is it?

$<<$ answer $>>$

Did the organization provide you with any training before you began your internship? When was your first day of training? How many days/hours of training? How was the training conducted?

$<<$ answer $>>$

When was your first day as an intern?

$<<$ answer $>>$

\section{Hours Worked:}

Including hours spent receiving on-site training, how many hours have you worked since you began your internship?

\begin{tabular}{clll} 
Week & Begin & End & Hours \\
\hline$\# 1$ & $<<$ date $>>$ & $<<$ date $>>$ & $<<$ hours $>>$ \\
$\# 2$ & $<$ date $>>$ & $<<$ date $>>$ & $<<$ hours $>>$ \\
$\# 3$ & $<<$ date $>>$ & $<<$ date $>>$ & $<<$ hours $>>$ \\
$\# 4$ & $<<$ date $>>$ & $<<$ date $>>$ & $<<$ hours $>>$
\end{tabular}

Answer the following questions:

I. What tasks have you completed during the first few weeks of your internship?

$<<$ answer $>>$ 
II. What new skills/knowledge have you developed during this period?

$<<$ answer $>>$

III. To what extent is the internship conforming to your expectations?

$<<$ answer $>>$

IV. Are you making progress in meeting the learning objectives you listed on your Internship Learning Objectives Form?

$<<$ answer $>>$

V. Are there any problems or concerns with the internship that you believe should be noted at this time? Do you need any assistance or advice to help find a solution to those problems/concerns?

$<<$ answer $>>$ 


\section{Appendix: Departmental Learning Outcomes, Department of Political Science, University of Oregon}

1. Recognize and describe major variations in political institutions and policy processes

- including variation over time among democracies, between democratic and nondemocratic systems, across issue areas within countries, and across levels of governance from local contexts to the global arena.

2. Recognize the roles played by various actors, groups, and movements in political and cultural processes

- including the social and material power resources to which they may have access, and factors that advantage certain social groups and exclude or marginalize others.

3. Identify the defining principles of major political ideologies and apply their perspectives to political issues

- including liberalism, conservatism, socialism, fascism, etc.

4. Describe how power, agency, and authority are constituted, disseminated, and exercised

- including similarities and differences within and across groups, countries, and in the international arena.

5. Analyze, interpret, and explain why and how political processes or policy outcomes vary

- including across countries, policy realms, and time.

6. Construct a sustained argument evaluating a theoretical claim against alternative theoretical traditions or perspectives and appropriate evidence

- including in a written paper, oral presentation, or other creative output.

7. Identify and describe several analytical methods that political scientists use to study political phenomena.

8. Demonstrate engagement with social and political issues

- including through politically-related employment or internships, regular critical reading about current events, or other forms of policy and political experience.

9. Produce clear and professional verbal and written communication

- including in the form of policy memos, individual or collective presentations, or research papers. 